\title{
PENGARUH SISTEM OLAH TANAH DAN APLIKASI HERBISIDA TERHADAP BIOMASSA KARBON MIKROORGANISME TANAH (C-MIK) PADA PERTANAMAN UBI KAYU (Manihot esculenta Crantz) TAHUN KE-2 DI TANAH ULTISOL GEDUNG MENENG BANDAR LAMPUNG
}

\author{
Tabroni, Sri Yusnaini, Ainin Niswati \& Muhajir Utomo \\ Jurusan Agroteknologi, Fakultas Pertanian, Universitas Lampung \\ Jl. Prof. Soemantri Brojonegoro, No. 1 Bandar Lampung 35145 \\ Email: tbtabroni@gmail.com
}

\begin{abstract}
ABSTRAK
Pengolahan tanah merupakan salah satu kegiatan yang umumnya dianggap wajib dalam berbudidaya tanaman yang dapat dilakukan secara olah tanah minimum (OTM), olah tanah intensif (OTI) maupun tanpa olah tanah (TOT). Sementara itu, aplikasi herbisida umumnya dilakukan guna meminimalisir pertumbuhan gulma yang merupakan pesaing tanaman dalam memanfaatkan ruang, cahaya, air dan unsur hara. Penelitian ini bertujuan untuk mengetahui pengaruh sistem olah tanah terhadap biomassa karbon mikroorganisme (C-mik) pada tanah yang ditanami ubi kayu, mengetahui pengaruh aplikasi herbisida terhadap biomassa karbon mikroorganisme (C-mik) pada tanah yang ditanami ubi kayu, dan mengetahui pengaruh antara interaksi sistem olah tanah dan pengaplikasian herbisida terhadap biomassa karbon mikroorganisme (C-mik) pada tanah yang ditanami ubi kayu. Penelitian ini dilaksanakan di Laboratorium Lapang Terpadu Fakultas Pertanian Universitas Lampung dengan menggunakan petak pertanaman ubi kayu di tanah ultisols sejak September 2014-Mei 2015 (musim tanam tahun kedua) dengan menggunakan Rancangan Acak Kelompok (RAK), terdiri atas empat ulangan dengan empat satuan percobaan untuk tiap ulangannya.Perlakuan yang diterapkan terdiri atas 2 faktor, faktor pertama adalah sistem olah tanah secara minimum (T0)dan intensif (T1), sedangkan faktor kedua adalah aplikasi herbisida yaitu tanpa penggunaan herbisida ( $\mathrm{H} 0)$ dan dengan penggunaan herbisida (H1) yang disemprotkan 3 bulan setelah tanam dan 6 bulan setelah tanam. Pengolahan tanah baik secara intensif maupun minimum tidak memberikan pengaruh yang signifikan terhadap biomassa karbon mikroorganisme tanah (C- mik) pada petak pertanaman ubi kayu musim kedua.Begitu pula dengan pengaplikasian herbisida yang juga tidak memberikan pengaruh yang signifikan terhadap biomassa karbon mikroorganisme tanah (C-mik), sehingga tidak terdapat interaksi antara sistem olah tanah dan aplikasi herbisida yang diterapkan pada petak pertanaman ubi kayu musim kedua terhadap karbon mikroorganisme tanah (C-mik).
\end{abstract}

Kata kunci: Biomassa karbon mikroorganisme tanah, herbisida, sistem olah tanah, tanaman ubi kayu

\section{PENDAHULUAN}

Pengolahan tanah umumnya dianggap wajib oleh petani dalam budidaya tanaman, sehingga selalu dianggap penting, sementara itu beberapa penelitian menunjukan pengolahan tanah secara intensif dapat menyebabkan penurunan kualitas tanah. Dampak negatif yang dapat ditimbulkan antara lain pemadatan pada tanah, berkurangnya ketersediaan air tanah, semakin kurang berkembangnya sistem perakaran tanaman, penurunan kandungan bahan organik, kerusakan struktur dan agregat tanah (Manik, Afandi, dan Soekarno, 1998). Manik et al.(1998) melaporkan bahwa penerapan sistem olah tanah intensif menyebabkan kepadatan tanah yang tinggi, terutama pada lapisan bawah bajak (kedalaman $30 \mathrm{~cm}$ ), menurunkan jumlah pori makro dan pori aerasi, serta lapisan atas (permukaan tanah) sangat peka terhadap erosi, terutama erosi percik. Sistem olah tanah seperti ini akan mempercepat degradasi tingkat kesuburan tanah akibat pencucian hara dan erosi, yang selanjutnya dapat menurunkan produktivitas lahan.

Salah satu penentu kesuburan tanah yang dapat terlihat adalah adanya aktivitas serta banyaknya mikroorganisme di dalam tanah. Hal ini mengingat bahwa bahan organik tanah dapat mengendalikan berbagai proses penting dalam tanah, seperti memasok hara melalui perubahan status $\mathrm{C}$ dan $\mathrm{N}$ sebagai unsur utama bahan organik tanah, meningkatkan agregasi tanah, meningkatkan ketersediaan air tanah, dan mengurangi kehilangan hara tanah (Utomo, 1995). Karbon mikroorganisme tanah (C-mik) merupakan mikroorganisme yang dapat dijadikan indikator penentu kesuburan tanah. Menurut Warsito (2008) dalam 
Wibowo (2013) bahan organik berperan penting terhadap biomassa karbon mikroorganisme (C-mik) tanah. Semakin tinggi keberadaan bahan organik maka aktivitas mikroorganisme akan semakin tinggi, sehingga diikuti oleh peningkatan biomassa karbon mikroorganisme (Cmik) tanah. Hal ini disebabkan kandungan bahan organik yang tinggi dalam tanah dapat dijadikan sebagai sumber energi mikroorganisme tanah sehingga C-mik dapat meningkat (Simanjuntak, 1997).

Selain olah tanah, penggunaan herbisida atau senyawa kimia untuk mengendalikan gulma di dalam dunia pertanian juga sering dilakukan oleh petani pada umumnya. Menurut Dermiyati (1997) sebagian besar herbisida yang diaplikasikan ketanaman akhirnya akan jatuh ke tanah, kemudian mengalami perubahan dan dalam waktu yang tertentu akan terjerap oleh fraksi liat dan bahan organik dalam tanah, yang secara umum dikenal sebagai residu herbisida. Residu herbisida beracun dalam tanah dapat membunuh mikroba tanah, yang sebenarnya bukan targetnya (non target microorganism) sehingga mengganggu aktivitas mikroorganisme tanah yang pada akhirnya dapat mempengaruhi siklus hara dalam tanah.

Penggunaan herbisida pada lahan pertanian juga berpengaruh terhadap perkembangan bahan organik tanah, dimana herbisida yang digunakan secara luas di Indonesia antara lain adalah herbisida yang mengandung bahan aktif glifosat yaitu $65 \%$ dari total herbisida yang beredar (Lamid dan Azwir, 1997). Glifosat merupakan herbisida yang mempunyai spektrum pengendali yang luas dan bersifat tidak selektif.Senyawa ini diserap melalui daun dan diangkut ke dalam semua jaringan tumbuhan. Cara kerjanya mempengaruhi asam nukleat dan sintesis protein (Sastroutomo, 1992). Glifosat umumnya digunakan untuk mengendalikan gulma tahunan, berdaun lebar dan digunakan pada peringkat pra-tumbuh dengan dosis penggunaan yang berbedabeda tergantung jenis gulma yang dikendalikan.

Tingginya persistensi bahan aktif yang dimiliki oleh herbisida akan memberikan efek terhadap populasi mikroorganisme dalam tanah. Moenandir (1990), mengemukakan bahwa dengan semakin banyaknya kandungan unsur-unsur toksik yang ada di dalam tanah akibat pemberian herbisida- herbisida yang relatif tahan terhadap biodegradasi akan sangat menghambat fungsi biodegradasi dari mikroorganisme dan bahkan dapat membunuh mikroorganisme yang ada di dalam tanah itu sendiri. Oleh karena itu, penelitian ini dilakukan untuk menjawab masalah yaitu apakah sistem olah tanah, penggunaan herbisida maupun interaksi di antara kedua faktor tersebut dapat berpengaruh terhadap biomassa karbon mikroorganisme (C-mik) pada petak pertanaman ubi kayu musim tanam tahun kedua. Adapun tujuan dari penelitian ini adalah mengetahui pengaruh sistem olah tanah terhadap biomassa karbon mikroorganisme (Cmik) pada tanah yang ditanami ubi kayu, mengetahui pengaruh aplikasi herbisida terhadap biomassa karbon mikroorganisme (C-mik) pada tanah yang ditanami ubi kayu, dan mengetahui pengaruh interaksi antara sistem olah tanah dan pengaplikasian herbisida terhadap biomassa karbon mikroorganisme (C-mik) pada tanah yang ditanami ubi kayu.

\section{BAHAN DAN METODE}

Penelitian dilaksanakan di Lab Lapang Terpadu FPUnila pada bulan September 2014 - Mei 2015. Analisis tanah dan biomassa karbon mikro organisme (C-mik) dilakukan di Lab Ilmu Tanah FP Unila. Alat yang digunakan adalah sekop, wadah plastik, alat tulis, timbangan, lakban, toples, desikator dan alat-alat laboratorium lainnya untuk analisis tanah. Bahan-bahan kimia yang digunakan adalah $\mathrm{CHCl}_{3}, \mathrm{HCl}, \mathrm{KOH}$, phenophtalin, metil orange.

Penelitian ini disusun dalam Rancangan Acak Kelompok (RAK) faktorial dengan 2 faktor. Faktor pertama adalah sistem olah tanah (T), yaitu Olah Tanah Intensif(T1) dan Tanpa Olah Tanah (T0). Faktor kedua adalah pengendalian gulma $(\mathrm{H})$, yaitu penggunaan herbisida berbahan aktif Isopropilamina glifosat 240 $\mathrm{g}^{-1}$ (H1) dan tanpa herbisida (H0). Kombinasi kedua faktor tersebut terdapat 4 perlakuan yaitu $\mathrm{T} 1 \mathrm{H} 1, \mathrm{~T} 1 \mathrm{H} 0$, T0H1, dan T0H0. Semua perlakuan diulang sebanyak 4 kali. Data yang diperoleh diuji dengan uji Bartlett dan aditivitas data diuji dengan uji Tukey. Jika asumsi terpenuhi data dianalisis dengan sidik ragam, perbedaan nilai tengah perlakuan diuji dengan uji Beda Nyata Terkecil (BNT) pada taraf 5\%.

Sampel tanah diambil dari lima titik dan diambil secara diagonal kemudian diaduk menjadi satu (komposit). Tanah pada penelitian ini diambil dari lahan yang merupakan tanah Ultisol yang sedang ditanami tanaman ubikayu dengan kedalaman 0-20 cm. Pengambilan sampel tanah dilakukan sebelum aplikasi herbisida. Kemudian tanah dimasukan kedalam kulkas dikarenakan analisis tidak dilakukan secara langsung. Hal ini dilakukan dengan tujuan untuk menghentikan aktifitas mikroorganisme sementara, sehingga kondisi mikroorganisme dalam tanah diharapkan tidak berubah. Proses pelaksanaan analisis tanah dilakukan dengan pengukuran C-mik tanah dengan menggunakan metode fumigasi-inkubasi (Jenkinson dan Powlson, 1976). Biomassa mikroorganisme tanah dihitung dengan rumus akhir (Veroney dan Paul, 1984 dalam Wibowo 2013): 


$$
\begin{aligned}
& \mathrm{C}-\mathrm{mik}=\frac{\left(\mathrm{mg} \mathrm{C}-\mathrm{CO}_{2} \mathrm{~kg}^{-1} 10 \text { hari }\right)_{\text {fumigasi }}-\left(\mathrm{mgC}-\mathrm{CO}_{2} \mathrm{~kg}^{-1} 10 \text { hari }\right)_{\text {non-fumigasi }}}{\mathrm{Ke}} \\
& \mathrm{mg} \mathrm{C}-\mathrm{CO}_{2} \mathrm{~kg}^{-1} 10 \text { hari }=\frac{(\mathrm{a}-\mathrm{b}) \times \mathrm{t} \times 120}{\mathrm{n}}
\end{aligned}
$$

Keterangan:

$\mathrm{a}=\mathrm{ml} \mathrm{HCl} \mathrm{untuk} \mathrm{contoh} \mathrm{tanah}$

$\mathrm{b}=\mathrm{ml} \mathrm{HCl} \mathrm{untuk} \mathrm{blanko}$

$\mathrm{n}=$ waktu inkubasi (hari)

$\mathrm{t}=$ normalitas $\mathrm{HCl}(0,1)$

$\mathrm{Kc}=0,41$

\section{HASIL DAN PEMBAHASAN}

Berdasarkan hasil analisis ragam menunjukkan bahwa perlakuan sistem olah tanah dan aplikasi herbisida tidak berpengaruh nyata terhadap jumlah C-mik pada 3 bulan setelah tanam (BST), 6 BST dan 11 BST. Hasil penelitian menunjukkan perlakuan olah tanah minimum dan intensif dengan atau tanpa herbisida tidak berpengaruh nyata terhadap jumlah C-mik pada tiap waktu pengamatan, begitupun dengan interaksi perlakuan olah tanah dan herbisida tidak memberi pengaruh terhadap jumlah C-mik pada tiap waktu pengamatan di lahan ubikayu (Tabel 1). Hasil penelitian menunjukkan bahwa sistem olah tanah dan aplikasi herbisida tidak berpengaruh nyata terhadap biomassa karbon mikroorganisme tanah (C-mik).

Pada Tabel 2 diketahui bahwa jumlah C-mik mengalami peningkatan sejak waktu pengambilan sampel pertama terhadap pengambilan sampel kedua (3 BST dan 6 BST). Sementara untuk pengambilan sampel ketiga (11 BST), tidak semua perlakuan mengalami peningkatan jumlah $\mathrm{C}$ - mik. Hasil uji T menunjukkan bahwa jumlah C-mik pada 3 BST ke 6 BST nyata berpengaruh artinya terjadi peningkatan jumlah C-mik di rentan waktu tersebut. Hal ini terus berlanjut pada waktu pengamatan 3 BST ke 11 BST, hasil uji T menunjukkan terjadi peningkatan $\mathrm{C}$-mik di rentan waktu tersebut. Namun pada pengamatan 6 BST ke 11 BST waktu tidak berpengaruh terhadap peningkatan jumlah C-mik (Tabel 2).

Pada semua perlakuan, C-mik terendah dijumpai pada pengamatan 3 BST dan mengalami peningkatan pada 6 BST, kemudian menurun pada $11 \mathrm{BST}$, kecuali pada perlakuan $\mathrm{T} 1 \mathrm{H} 0$ dan $\mathrm{T} 0 \mathrm{H} 1$ yang mengalami sedikit peningkatan (Gambar 1). Adanya peningkatan C-mik pada petak perlakuan olah tanah minimum (OTM) disebabkan oleh adanya mulsa alami yang berasal dari gulma yang terdekomposisi yang dapat dimanfaatkan oleh mikroorganisme sebagai sumber energi. Sementara
OTI juga dirasa menguntungkan karena setelah diolah, tanah cenderung lebih gembur sehingga memicu pertumbuhan mikroorganisme.

Hubungan antara beberapa sifat kimia tanah dengan biomassa karbon mikroorganisme tanah $(C$ $m i k)$. Berdasarkan hasil pengamatan $\mathrm{pH}$ tanah mengalami penurunan namun masih dalam kriteria agak masam $(6,15-6,51)$ pada seluruh perlakuan di setiap waktu pengamatan. Sementara itu jumlah C- organik di seluruh perlakuan pada tiap waktu pengamatan termasuk rendah berkisar $0,99-1,73 \%$. Terjadi peningkatan suhu pada setiap perlakuan di tiap waktu pengamatan, suhu masuk dalam kriteria hangat dengan kisaran $26,90-29,45^{\circ} \mathrm{C}$. Kadar air pada setiap perlakuan dan waktu pengamatan berada pada kisaran 28,44 $35,77 \%$.

Hasil uji korelasi menunjukkan C-mik tidak berkorelasi dengan beberapa sifat kimia tanah pada pengamatan 3 BST dan 11 BST (Tabel 4). Grafik korelasi menunjukkan pada setiap peningkatan $\mathrm{C}$ - organik sebesar $60,67 \%$ terjadi penurunan jumlah C-mik sebesar - 17,58 $\mathrm{mg} \mathrm{C}-\mathrm{CO}_{2} / 100 \mathrm{~g}$ tanah, artinya pada saat C-organik meningkat terjadi penurunan jumlah C-mik. (Gambar 2).

Berdasarkan penelitian ini diamati jumlah C-mik pada tiap waktu pengamatan berbeda (3, 6 dan 11 BST) yang diberi perlakuan olah tanah dan herbisida. Hasilnya menunjukkan terjadi peningkatan jumlah C-mik dari waktu pengamatan 3 BST ke 6 BST, namun pada pengamatan selanjutnya terjadi penurunan jumlah C-mik pada waktu pengamatan 6 BST ke 11 BST pada perlakuan T0H0 dan T1HI (Gambar 1). Adanya penurunan jumlah C-mik dalam kurun waktu 6 BST ke 11 BST diduga karena pada perlakuan $\mathrm{T} 1 \mathrm{H} 1$ sistem olah tanah intensif yang diterapkan telah mempengaruhi faktor lingkungan tumbuh mikroorganisme. OTI banyak mengakibatkan adanya perubahan sifat-sifat tanah yang mempengaruhi kondisi di dalam tanah seperti keberadaan mikroorganisme dan ketersediaan oksigen bagi mikroorganisme yang berkurang akibat perubahan agregat dan aerasi tanah sehingga mengakibatkan terjadinya penurunan. Pengaplikasian herbisida diduga memberikan residu pada tanah yang bersifat toksik bagi mikroorganisme dalam tanah. Selain itu penurunan jumlah $\mathrm{C}$-mik diduga akibat $\mathrm{pH}$ tanah yang agak asam dan suhu yang tidak optimal bagi sebagian jenis mikroorganisme tanah, kondisi tanah yang tidak sesuai 
Tabel 1. Pengaruh waktu pengamatan dan perlakuan terhadap C-mik pada pertanaman ubikayu

\begin{tabular}{lccc}
\hline \multirow{2}{*}{ Perlakuan } & \multicolumn{3}{c}{ Waktu Pengamatan } \\
\cline { 2 - 4 } & 3 BST & 6 BST & 11 BST \\
\hline T0H0 & 26,22 & 38,78 & 35,63 \\
T0H1 & 24,22 & 35,37 & 36,29 \\
T1H0 & 20,56 & 39,30 & 40,31 \\
T1H1 & 21,93 & 30,04 & 29,12 \\
\hline Olah Tanah & 3,16 tn & $0,61 \mathrm{tn}$ & $0,18 \mathrm{tn}$ \\
Herbisida & $0,02 \mathrm{tn}$ & $4,27 \mathrm{tn}$ & $3,20 \mathrm{tn}$ \\
Interaksi & $0,57 \mathrm{tn}$ & $0,91 \mathrm{tn}$ & $4,04 \mathrm{tn}$ \\
\hline
\end{tabular}

Keterangan: $\mathrm{T} 0=$ Olah tanah minimum; $\mathrm{H} 0=$ Tanpa herbisida; $\mathrm{T} 1=$ Olah tanah intensif; $\mathrm{H} 1=$ Aplikasi herbisida; $*$ = beda nyata pada taraf $5 \%$, tn $=$ tidak berbeda nyata pada taraf $5 \%$

Tabel 2.Uji T pengaruh waktu pengamatan terhadap C-mik pada pertanaman ubikayu

\begin{tabular}{ccc}
\hline Waktu (BST) & T Hitung & T Tabel \\
\hline 3 vs 6 & $5,99^{*}$ & 2,13 \\
3 vs 11 & $4,54^{*}$ & 2,13 \\
6 vs 11 & $-0,13$ tn & 2,13 \\
\hline
\end{tabular}

Keterangan: $*$ = beda nyata pada taraf $5 \%, \mathrm{tn}=$ tidak berbeda nyata pada taraf $5 \%$

Tabel 3. Perubahan sifat tanah akibat perlakuan

\begin{tabular}{ccccccccccccc}
\hline P & \multicolumn{4}{c}{3 BST } & \multicolumn{1}{c}{ 6 BST } & \multicolumn{4}{c}{11 BST } \\
\cline { 2 - 14 } & pH & C-org & S & KA & pH & C-org & S & KA & pH & C-org & S & KA \\
\hline T0H0 & 6,33 & 1,60 & 26,90 & 31,53 & 6,51 & 1,42 & 29,45 & 30,26 & 6,26 & 1,16 & 29,05 & 32,97 \\
T0H1 & 6,24 & 1,67 & 27,05 & 28,44 & 6,21 & 1,33 & 28,78 & 29,91 & 6,15 & 0,99 & 29,20 & 32,37 \\
T1H0 & 6,27 & 1,55 & 27,45 & 35,77 & 6,37 & 1,39 & 28,93 & 30,81 & 6,18 & 1,22 & 29,02 & 31,93 \\
T1H1 & 6,27 & 1,73 & 27,43 & 34,36 & 6,48 & 1,67 & 28,90 & 29,45 & 5,95 & 1,12 & 29,05 & 34,61 \\
\hline
\end{tabular}

Tabel 4.Uji korelasi antara pH, C-organik dan suhu tanah terhadap C-mik

\begin{tabular}{lccc}
\hline \multirow{2}{*}{ Variabel } & \multicolumn{3}{c}{ Biomassa Karbon Mikroorganisme $\left(\mathrm{mg} \mathrm{C}-\mathrm{CO}_{2} \mathrm{~kg}^{-1}\right.$ hari $\left.^{-1}\right)$} \\
\cline { 2 - 4 } & \multicolumn{3}{c}{ Nilai r } \\
\cline { 2 - 4 } & $0,040 \mathrm{tn}$ & $6 \mathrm{BST}$ & $11 \mathrm{BST}$ \\
\hline $\mathrm{pH}$ & $0,033 \mathrm{tn}$ & $0,0033 \mathrm{tn}$ & $0,0003 \mathrm{tn}$ \\
$\mathrm{C}$-organik & $0,010 \mathrm{tn}$ & $0,4810 \mathrm{tn}$ & $0,0160 \mathrm{tn}$ \\
Suhu & $0,011 \mathrm{tn}$ & $0,1410 \mathrm{tn}$ & $0,0080 \mathrm{tn}$ \\
Kadar air tanah & $0,0006 \mathrm{tn}$ & $0,0061 \mathrm{tn}$ \\
\hline
\end{tabular}

Keterangan: $\mathrm{r}=$ koefisien korelasi linier, $*=$ berbeda nyata taraf $5 \%, \mathrm{tn}=$ tidak berbeda nyata taraf $5 \%$. 


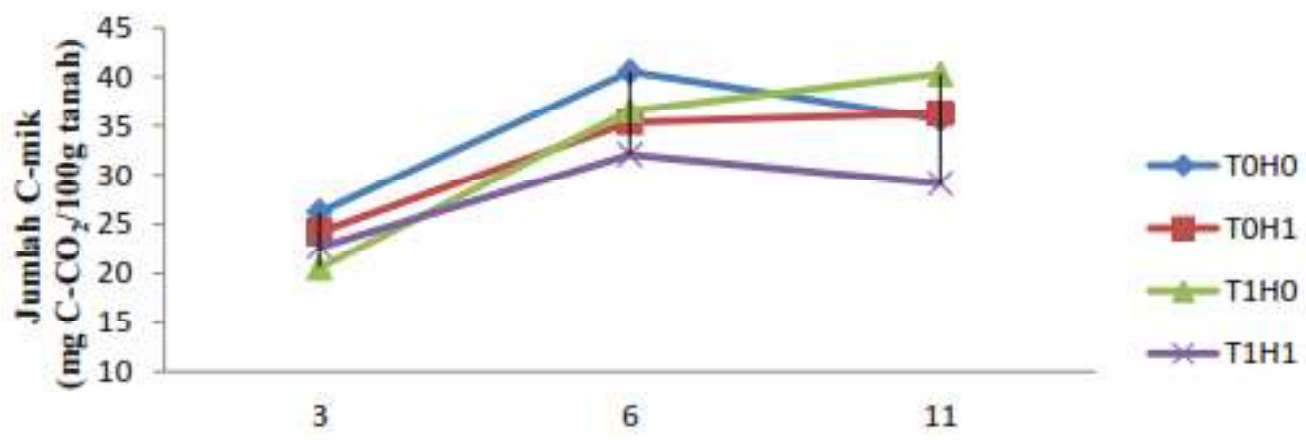

Waktu pengamatan (BST)

Gambar 1. Grafik perkembangan C-mik. T0 = Olah tanah minimum; H0 = Tanpa herbisida; $\mathrm{T} 1=$ Olah tanah intensif; $\mathrm{H} 1$ = Aplikasi herbisida.

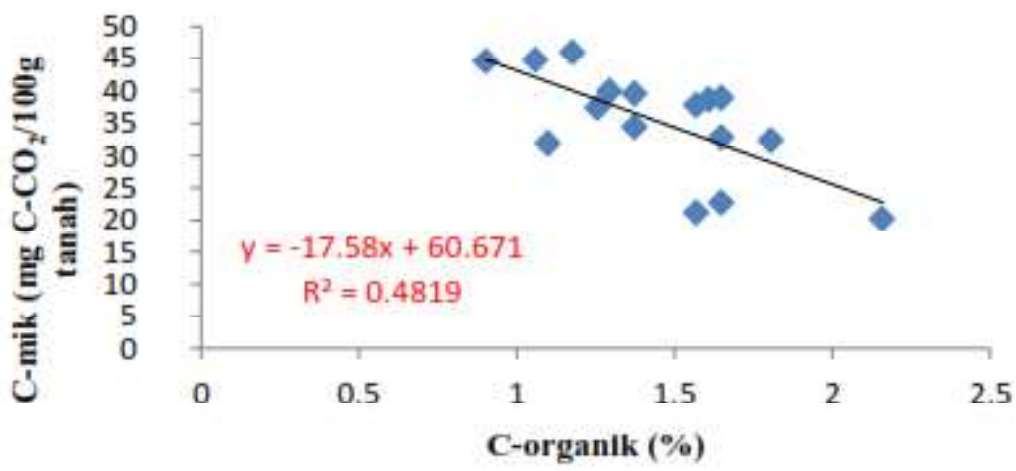

Gambar 2. Korelasi antara C-organik tanah dengan C-mik tanah pada pengamatan 6 BST.

dapat menyebabkan penurunan jumlah C-mik dalam tanah. Berdasarkan data uji korelasi antara C-mik dengan beberapa sifat kimia tanah seperti $\mathrm{pH}$, C-organik, suhu tanah dan kadar air tanah diketahui tidak menunjukan korelasi nyata. Tidak adanya korelasi yang nyata dipengaruhi oleh waktu penelitian yang pada saat dilaksanakan berada pada musim tanam pada tahun kedua sehingga korelasi antara $\mathrm{C}$-mik dengan beberapa sifat kimia tanah belum menunjukkan signifikansi.

Hasil uji korelasi menunjukkan penurunan jumlah C-mik seiring meningkatnya jumlah C-organik tanah. Hal ini diduga pada tanaman ubi kayu proses pembentukan umbi membutuhkan hara yang cukup tinggi, sehingga C-organik dalam tanah banyak diserap oleh tanaman dan kurang dimanfaatkan oleh mikroorganisme tanah. Kondisi tanah yang kurang optimal dan tanaman yang membutuhkan banyak hara untuk pembentukan umbi menyebabkan tidak terjadi peningkatan jumlah C-mik dalam tanah.

\section{KESIMPULAN}

Berdasarkan hasil penelitian yang dilakukan dan pembahasan diperoleh kesimpulan yaitu baik sistem olah tanah, aplikasi herbisida maupun kombinasi diantara kedua faktor yang diterapkan pada pertanaman ubi kayu musim ke dua tidak berpengaruh terhadap biomassa karbon mikroorganisme tanah (C-mik).

\section{DAFTAR PUSTAKA}

Dermiyati.1997. Pengaruh Mulsa terhadap Aktivitas Mikroorganisme Tanah dan Produksi Jagung Hibrida C-1. J. Tanah Trop. Vol. 5: 63-68.

Iswandi, G., D. A. Santoso, dan D.R. Widyastuti. 1995. Penggunaan Ciri Mikroorganisme dalam Mengevaluasi Degradasi Tanah. Kongres Nasional VI HITI, 12-15 Desember 1995. Serpong.

Jenkinson, D.S. dan D.S Powlson. 1976. The Effect of Biocidal Treatments On Metabolism in soil V. A method for measuring biomass. Soil Biol. Biochem. Vol.8: 209-213.

Lamid, Z. dan Azwir. 1997. Tingkat penggunaan herbisida dewasa ini dan dampaknya terhadap sumberdaya lingkungan. Balai Pengkajian Teknologi Pertanian Sukarami. Solok. 
Manik, K.E.S, Afandi, dan Soekarno. 1998. Karakteristik tanah pada perkebunan nanas yang diolah sangat intensif di Lampung Tengah. $J$. Tanah Tropika. (7): 1-6.

Moenandir, J. 1990. Fisiologi Herbisida. Rajawali Press. Jakarta.

Sastroutomo. S. S. 1992.Pestisida, Dasar-Dasar dan Dampak Penggunaannya. Gramedia Pustaka Utama, Jakarta. $168 \mathrm{hlm}$.

Simanjuntak, B.H. 1997. Pengaruh Pemberian Pupuk Kandang dan Blue Green Algae Terhadap Sifat Fisik dan Biologi Tanah Ultisol serta Produksi Kedelai (Glecyne max L) varietas Willis. Disertasi.Program Pasca Sarjana Institut Pertanian Bogor.

Sucipto. 2011. Pengaruh Sistem Olah Tanah dan Aplikasi Mulsa Bagas terhadap Kandungan Biomasssa
Karbon Mikroorganisme Tanah Pada Pertanaman Tebu PT Gunung Madu Plantations. Skripsi. Universitas Lampung. Bandar Lampung, $58 \mathrm{hlm}$.

Utomo, M. 1990. Budidaya Tanpa Olah Tanah Teknologi Untuk Pertanian Berkelanjutan. Direktorat Produksi Padi dan Palawija. Departemen Pertanian RI. Jakarta.

Utomo, M. 1995. Kekerasan Tanah dan Serapan Hara Tanaman Jagung pada Olah Tanah Konservasi Jangka Panjang. J. Tanah Trop. 1: 1-7.

Wibowo, Y.S. 2013. Pengaruh Sistem Olah Tanah pada Lahan Alang-alang (Imperata cylindrica) terhadap Biomasa Karbon Mikroorganisme Tanah (C-mik) yang Ditanami Kedelai (Glycine max L) MusimKedua. Skripsi. Fakultas Pertanian Universitas Lampung. Bandar Lampung. 